\title{
ENZYME LINKED IMMUNOSORBENT ASSAY: DETERMINATION OF ANTI-ADENOVIRUS ANTIBODIES IN AN INFANT POPULATION
}

\author{
Adriana WEINBERG (1), Maria Cristina D. S. FINK (1), Sueko TAkIMOTO (2), Maria Mkiko ISHIDA (2)
}

Maria Candida O. SOUZA (2)

\begin{abstract}
SUMMARY
In order to define an accurate assay for anti adenovirus antibody detection. a recently developed ELISA was compared with IFA and CF. On 58 sera, the ELISA was more sensitive than both $\mathrm{CF}$ and IFA, which showed relative sensitivities of $63^{\prime}$, and $94^{\prime}$, respectively. It was not possible to determine the exact specificity of the tests because of the lack of a gold standard. Furthermore, the ELISA was used to define the prevalence of adenovirus antibodies in 116 infants between 1 and 24 months old (mean 7.28). The data showed that maternal antibodies waned by the age of 5 to 6 months and that more than $80 \%$ of the children had been infected by adenoviruses by the age of 10 months.
\end{abstract}

KEY WORDS: Adenovirus serology: Enzyme linked immunosorbent assay: Adeno virus infection in children.

\section{INTRODUCTION}

Adenoviruses (Ad) are ubiquitous human pathogens that commonly produce benign respi ratory, gastrointestinal, urinary and ocular di seases. However, adenovirus infections may be extremely severe and often lethal in immuno compromised hosts such as transplant reci pients, cancer patients undergoing chemothera py, children with severe combined immunodefi ciency and AIDS patients. 4. 1. 11. 1". Previous studies in transplant patients have suggested that the most likely source of infection was endo genous reactivation of latent virus ${ }^{12}$. In this po pulation routine surveys are very important to identify the individuals at risk of developing ade novirus disease.
Laboratory diagnosis of adenovirus infec tions has relied on recognition of cytopathic effect in tissue culture, monoclonal antibodies mediated rapid detection ". "or significant increases of antibody titers in paired sera. Anti-Ad IgM antibody assays have not yet been standardized. With the recent advances in antiviral therapy, sensitive diagnostic methods are needed to dis close the infectious agents early in the course of the disease and to determine the candidates to antiviral prophylaxis ${ }^{10}$.

The goal of the present study was to test the diagnostic accuracy of an IgG anti-Ad ELI$\mathrm{SA}$ developed in our laboratory. We also exami-

This work was supported by CNPq grant n: 40874188

(1) Virology laboratory of the Instituto de Medicina Tropical Sao Paulo: LIM 52 HC FMUSP. Sào Paulo. Brasil

12) Respiratory virus laboratory of the Instituto Adolfo Lutz. Sao Paulo. Brasil.

Iddess for correspondence: Dra. Adriana Weinberg. Laboratorio de Virologia. Instituto de Medicina Tropical de Sao Paulo. Av. Dr. Enfas de Carvalho Aguiar. 470. CEP 05403 Sá Paulo. SP. Brazil. 
WEINBERG, A.; FINK, M. C. D. S.; TAKIMOTO, S.; ISHIDA, M. A \& SOUZA, M. C. O. - Enzyme linked immunosorbent assay: determination of anti-adenovirus antibodies in an infant population. Rev. Inst. Med. trop. S. Paulo, 31(5): 336-340, 1989.

ned the prevalence of adenovirus infection in young children in order to complete previous epidemiologic surveys and establish back ground information of adenovirus risk of infection for pediatric transplant patients in our environment.

\section{MATERIAL AND METHODS}

Viruses and cells. KB, Hep 2 and human foreskin fibrobast (HFF) tissue cultures were maintained at $37^{\circ} \mathrm{C}$ in Eagle's minimum essential medium (MEM) (Gibco, Grand Island, NY) complemented with $10 \%$ fetal calf serum (FCS) (Cultilab, Campinas, $\mathrm{SP}$ ) and $100 \mathrm{U} / \mathrm{ml}$ penicillin, $100 \mu \mathrm{l} / \mathrm{ml}$ streptomycin and $2 \mu \mathrm{l} / \mathrm{ml}$ amphotericin B. Ad 5 was propagated on Hep 2 and $\mathrm{KB}$ cells in MEM containing $2 \%$ FCS and antibiotics. In fectivity was measured by $\operatorname{TCID}_{50}$ in $\mathrm{KB}$ tissue culture tubes or by plaque fomation on HFF as previously described ${ }^{15}$. Titers varied between $10^{5}$ plaque forming units $/ \mathrm{ml}$ and $10^{7} \mathrm{TCID}_{50}$ ones.

Serum samples. 116 blood samples were obtained from children visiting the vaccination centers of the Hospital do Servidor Público Estadual and Hospital das Clínicas da FMUSP. The sera were stored at $-20^{\circ} \mathrm{C}$ until tested. Another 58 serum samples from patients referred to the Instituto Adolfo Lutz for clinically suspected adenovirus infection were used for the comparison of the anti-Ad antibody detection methods.

\section{Antibody detection.}

The complement fixation (CF) technique used for anti-Ad antibody determinations was already published ${ }^{13}$.

ELISA for anti-Ad antibodies was adapted from a previous publication ${ }^{14}$. Briefly, the antigen was prepared from 3 day old Ad 5 infected $\mathrm{KB}$ monolayers at complete $\mathrm{CPE}$ and mock in fected $\mathrm{KB}$ tissue cultures. Cells were washed in phosphate buffered saline (PBS), $\mathrm{pH} 7.6$, and resuspended in $0.1 \mathrm{M}$ glycine in PBS at a volume 10 times greater than the packed cell volume. The suspension was sonicated, solubilized with 1\% Tween 80 (Merck, Rio de Janeiro, RJ) and clarified by centrifugation. 96 well microtiter plates (Hemobag, Campinas, SP) were coated with viral and mock antigen and the suspensions we- re allowed to evaporate overnight at $37^{\circ} \mathrm{C}$. The optimal antigen dilution was found by checkerboard titration using a serum of known anti-Ad antibody titer. The plates were sealed in plastic bags and stored at $-20^{\circ} \mathrm{C}$ until used. There was no detectable loss in antigenicity after 4 months of storage. Before use, the plates were washed with PBS containing $0.5 \%$ Tween 80 (TPBS) and uncoated sites were blocked with $1 \%$ bovine serum albumin (BSA) in TPBS. Duplicates of $1 / 20$ dilutions of the test sera in TPBS containing $1 \%$ BSA were added to the viral and mock coated wells and incubated for $30 \mathrm{~min}$ at $37^{\circ} \mathrm{C}$. Then, the plates were washed and incubated with goat anti-human IgG antibodies conjugated to horseradish peroxidase (Sigma, St. Louis, Mo). The reaction was revealed with o-phenylenediamine (Sigma) and read with a Titertek Multiskan MK II (Flow, McLean, Vi). Specific binding was considered to occur when the difference between the mean absorbance in viral and mock antigen wells was higher than 0.1 .

Indirect immunofluorescence assay. Two day old Ad 5 infected Hep 2 monolayers and uninfected controls were washed, resuspended in PBS and acetone fixed onto slides at a concentration of 30 to 50 cells per $400 \mathrm{x}$ high power field. Thereafter, $25 \boldsymbol{\mu l}$ of $1 / 10$ diluted serum samples were added to the slides and incubated for $30 \mathrm{~min}$ at $37^{\circ} \mathrm{C}$ in a wet chamber. Then, the slides were washed with PBS and incubated with antihuman IgG fluorescent conjugate (Sigma) for 30 min at $35^{\circ} \mathrm{C}$. After another $5 \mathrm{~min}$ incubation with Evans' blue, the slides were washed, mounted in $90 \%$ glycerine in PBS and read with a $50 \mathrm{~W}$ Nikon epifluorescent microscope.

\section{RESULTS}

\section{Comparative analysis of ELISA, CF and IF $A$ for anti-Ad antibodies detection.}

In order to determine the diagnostic power of the newly developed anti-Ad ELISA, 58 sera obtained from patients with clinically suspected adenovirus infection were tested for specific antibodies using ELISA, as well as previously established IFA and CF. Table 1 shows that the ELI SA test displayed the highest sensitivity, 57 positive results, followed by IFA, 54 seropositives ( $94 \%$ sensitivity compared with ELISA) and at 
WEINBERG, A.: FINK, M. C. D. S.; TAKIMOTO, S.; ISHIDA, M. A \& SOUZA, M. C. O. - Enzyme linked immunosorbent assay: determination of anti-adenovirus antibodies in an infant population. Rev. Inst. Med. trop. S. Paulo, 31(5): $336-340,1989$.

TABLE 1

Comparative anti-Ad antibody detection by ELISA, IFA and $\mathrm{CF}$ in 58 sera.

\begin{tabular}{lcc}
\hline & Seropositives & Seronegatives \\
ELISA & 57 & 1 \\
IFA & 54 & 4 \\
CF & 36 & 22 \\
\hline
\end{tabular}

last the $\mathrm{CF}$ (36 seropositives) with a sensitivity of $63 \%$ compared with ELISA and $66 \%$ compared with IFA. All the samples seropositive by $\mathrm{CF}$ were also positive by ELISA. In contrast, one of the CF and ELISA positive sera was negative in the IFA assay, indicating the lower sensitivity of IFA compared to ELISA. The serum that was negative for anti-Ad antibodies by ELISA resulted also negative with the use of the other two tests. Two sera were positive by ELISA and negative according to both CF and IFA assays.

\section{Anti-Ad antibody prevalence in infants} from the city of São Paulo

116 serum samples obtained from children between 1 and 24 months of age, mean of 7.28 months, were tested for the presence of anti-Ad antibodies using ELISA, as shown in Fig. 1. The data indicate that infants of less than 4 months of age have a high prevalence, close to $100 \%$ of anti-Ad antibodies, most of them probably acquired intrauterus. At the age of 5 to 6 months the curve shows a nadir, suggesting the loss of

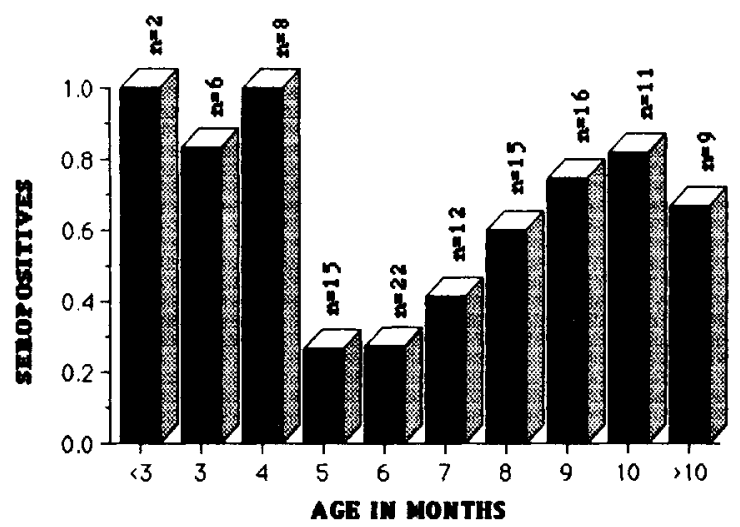

Fig. 1 - The data were derived from 116 sera tested by ELISA for anti-Ad antibodies presence. $\mathrm{n}=$ number of sera in each group. maternal antibodies. However, after 7 months of age the anti-Ad antibody level increases again reaching $85 \%$ positivity at 10 months. This last raise represents newly acquired anti-Ad antibodies as a consequence of Ad infection in the study population.

\section{DISCUSSION}

In this study, we showed that the ELISA was more sensitive for anti-Ad antibodies detection than $\mathrm{CF}$ and IFA, which displayed relative sensitivities of $63 \%$ and $94 \%$, respectively. Our results are in accordance with data obtained in other studies? ${ }^{7}$, where the ELISA had both higher sensitivity and specificity when compared with IFA or CF. However, in our system, it was difficult to assess the specificity of the ELISA, since the two sera which were antibody positive by ELISA and negative by CF and IF A could represent either false positive ELISA results, or false negative $C F$ and IFA ones. These differences could not be ascribed to the specificity of the antigens employed in the three assays, since all of them used the same Ad 5 strain for viral antigen preparation. The Ad 5 has been previously shown to extensively cross react with antibodies to the other known Ad strains, by CF and ELI$\mathrm{SA}^{7}$. However, this observation does not hold true for anti-Ad neutralizing antibodies, which are highly type specific. Therefore, although the neutralization reaction represents the gold standard for anti-Ad antibodies determination, it could not be used in this study, because we did not know which strains had infected the patients whose sera were tested. The accuracy of IF A was very close to the ELISA one in this study, but the ELISA offers additional advantages, since it is an uncomplicated test to perform and, in contrast to IFA, it is automatically read and does not depend on the visual skills of the lab technologist.

We also found a high prevalence of anti-Ad antibodies in the infants from the city of Sāo Paulo. The antibody curve showed a sudden fall from more than $95 \%$ seropositives before 4 months of age, to $27 \%$ positive samples at 5 and 6 months of age. The nadir most probably represented the loss of maternal antibodies. Thereafter, there was a steady increase in the prevalence of antiAd antibodies, indicating true adenovirus infec- 
WEINBERG, A.; FINK, M. C. D. S.; TAKIMOTO, S.; ISHIDA, M. A \& SOUZA, M. C. O. - Enzyme linked immunosorbent assay: determination of anti-adenovirus antibodies in an infant population. Rev. Inst. Med. trop. S. Paulo, 31(5) $336-340,1989$.

tions in this population, so that after 9 months of age more than $80 \%$ of the children had been in contact with these viruses. These findings are in accordance with previous studies ${ }^{1 .}{ }^{13}$ which demonstrated that although adenoviruses ac counted for $5.4 \%$ of the respiratory infections in infants between 0 and 24 months of age, in Sáo Paulo, these viruses could not be isolated from children younger than 4 months. Moreover, it has already been shown that, in the city of São Paulo. after the age of 2 years $76.6 \%$ of the popula tion had anti-Ad antibodies by $\mathrm{CF}^{3}$. The data pre sented in our study support the conclusion that most of the primary adenovirus infections are al ready acquired by the age of 10 months. However, the presence of anti-Ad antibodies does not necessarily mean protection against disease, be cause neutralizing defenses are very much type specific and reinfections with different serotypes are quite frequent. Furthermore, the adenoviruses may become latent and in the immunocompromised hosts the reactivations, although less frequent than with herpesviruses, can carry an equally high morbidity. In view of the present expansion of immunosuppressive therapeutic regimens, routine surveys of adenovirus reactivations or reinfections are needed, beginning at young ages and particularly in bone marrow and liver transplant patients which appear to bear the highest risk of fatal adenovirus infection ${ }^{2}$ 10,11 .

In conclusion, our data have demonstrated that ELISA is a highly sensitive test for anti-Ad antibodies detection, superior to $\mathrm{CF}$ and IFA. We have also shown that adenoviruses start to spread, in São Paulo, at very early ages and that more than $80 \%$ of the children are at risk of reac tivation upon immunosuppression.

\section{RESUMO}

Ensaio imunoenzimático: Detecção de anticorpos anti-adenovirus numa população infantil de São Paulo.

Com a finalidade de encontrar um ensaio preciso para a deteç̧âo de anticorpos anti-ade novírus, o teste ELISA recentemente padronizado foi comparado à imunofluorescência indi reta (IFI) e à fixaçāo de complemento (FC). Após testar 58 soros, o ELISA demonstrou maior sen sibilidade do que a IFI e a FC, que mostraram sensibilidades relativas de $94 \%$ e $63 \%$, respecti vamente. A falta de um padrāo universal nāo permitiu alcançar conclusōes definitivas quanto à especificidade dos ensaios. Além disso, o ELI SA foi utilizado para estabelecer a prevalência de anticorpos anti-adenovírus em 116 crianças entre 1 e 24 meses de idade (média 7.28). Os dados mostraram que os anticorpos maternos desapa recem ao redor dos 5 a 6 meses de idade e que mais de $80 \%$ das crianças tinham sido infectadas antes dos 10 meses de idade.

\section{AKNOWLEDGEMENTS}

We thank dr. Cláudio S. Pannuti for carefully reviewing this manuscript.

\section{REFERENCES}

1. ARAÚJO. J. \& TAKIMOTO, S. - Viroses respiratórias no lactente. Pediat. prát. (S. Paulo), 42: $203209,1971$.

2. BREINIG, M. K; ZITELLI, B.: STARZL, T. E. \& MONTO H. - Epstein Barr virus, cy tomegalovirus and other viral infections in children after liver transplantation, J. infect. Dis., 156: 273.279, 1987

3. CARvalho, R. P. S. - Contribuiçāo para o estudo do adenovirus. Sāo Paulo, 1960. 'Tese de doutoramento Faculdade de Medicina da Universidade de Sáo Paulo:

4. CUNNINGHAM, A. L.; GROHMAN, G. S.; HARKNESS J.; LAW, L.; MARRIOTT, D.; TINDALL, B. \& COOPER, D. A. - Gastrointestinal viruses and AIDS. J. infect. Dis. 158: 386391,1988

5. ESPY, M. J ; HIERHOLER, J. C. \& SMITH, T. F. - The effect of centrifugation on the rapid detection of adeno virus in shell vials. A mer. J. clin. Path., 88: 358 360, 1987.

6. HERRMANN, J. E.: PERRON HENRY, D. M. \& BLACK LOW. N. R. - Antigen detection with monoclonal antibo dies for the diagnosis of adenovirus gastroenteritis. J. infect. Dis, 155: 11671171,1987

7. HERRMANN, K. L. - Antibody detection. In: LENNET TE, E. H.; HALONEN, P.\& MURPHY, F. A. - Laboratory diagnosis of infectious diseases. Principles and practice. New York, Springer Verlag. 1988. v. 2, p. 76.101

8. KOC, J.; WIGAND, R. \& WEIL, M. - The efficiency of various laboratory methods for the diagnosis of adeno virus conjunctivitis. Zbl. Bakt. Microbiol. Hyg., 263A $607-615,1987$.

9. KONERU, B ; JAFFE, R.; ESQUIVEL, C. O : KUNZ, R. TODO, S.; IWATSUKI, S. \& STARZL, T. E. - Adenoviral infections in pediatric liver transplant recipients. J. A mer. med. Assoc., 258: 489.492, 1987 
WEINBERG. A.: FINK, M. C. D. S.: TAKIMOTO, S.: ISHIDA, M. A \& SOUZA, M. C. O. - Enzyme linked immunosorbent assay: determination of anti-adenovirus antibodies in an infant population. Rev. Inst. Med. trop. S. Paulo, 31(5): $336340,1989$.

10. LANDRY, M. L.; FONG, C. K. Y.; NEDDERMANN, K.: SOLOMON, L. \& HSIUNG, G. D. - Disseminated adeno virus infection in an immunocompromise host. Pitfalls in diagnosis. Amer. J. Med., 83: 555 558, 1987.

11. OKANO, M.: THIELE, M.; DAVIS, J.R R NAUSSEEF, W M.; MITROS, F. \& PURTILO, D. T. - Adenovirus type 2 in a patient with lethal hemorrhagic colonic ulcers and chronic active Epstein-Barr virus infection. Ann. intern. Med., 108: 693 699, 1988.

12. SHYELDS. A. F.: HACKMAN. R. C.: KENNETH. H. F. COREY, L. \& MEYERS, J. D. - Adenovirus infections in patients undergoing bone-marrow transplantation. New Engl. J. Med., 312: 529.533, 1985

13. TAKIMOTO, S.: ARAUJO, J.: FISCHER. A. R.: MARTI NEZ.C.H. O. \& VALLE. L. A. R. - Estudo sobre infeccóes causadas por vírus respiratórios em crianças de Sảo Pau lo. II Adenovírus: isolamento e estudo sorológico. Rev Inst. Med. trop. S. Paulo, 11: 348 357, 1969.

14. WEINBERG, A.; BASHAM, T. Y. \& MERIGAN, T. C. Regulation of the guinea pig immune functions by inter leukin-2: critical role of natural killer activity in acute HSV 2 genital infection. J. Immunol., 137: $33103317,1987$.

15. WEINBERG, A.; RASMUSSEN, L. \& MERIGAN, T. C - Acute genital infection in guinea pigs: effect of recom binant interleukin 2 on herpes simplex virus type 2 . J. in. fect. Dis., 154: 134-140, 1986.

16. ZAHRADNIK, J. M.; SPENCER, M. J. \& PORTER, D. D. - Adenovirus infection in the immunocompromised patient. Amer. J. Med., 68: 725 732, 1980

Recebido para publicaçāo em 13/6/1989 